\title{
Дуниты из гипербазитового массива зоны Главного Уральского разлома (Полярный Урал): минералогия, геохимия и условия образования
}

\author{
(C2021 Н. С. Уляшева ${ }^{\square}$ \\ Институт геологии имени академика Н. П. Юикина Коми науиного центра \\ Уральского отделения Российской академии наук, ул. Первомайская, \\ 54, 167982, Сыктывкар, Российская Федерация
}

\begin{abstract}
Аннотация
Bведение: На Полярном Урале в районе Главного Уральского разлома (ГУР) в верхнепротерозойских отложениях няровейской серии западной тектонической зоны локализованы дунитгарцбургитовые тела с неустановленным генезисом. Они представляют собой либо окраинноконтинентальные рифтогенные образования нижнего-среднего ордовика, либо тектоническиэрозионные клипы расположенного восточнее дунит-гарцбургитового комплекса офиолитового массива Сыум-Кеу. Целью работы является установление условий образования гипербазитовых тел на основании минералого-геохимического изучения дунитов из массива района оз. Ингилор.

Методика: Проведены петрографические, петрогеохимические и минералогические исследования дунитов с использованием прецизионных методов. Изучены структурные особенности и составы пород и минералов (хромшпинелидов и оливинов) из ультрамафитов, являющиеся чуткими индикаторами мантийных и коровых процессов.

Результаты и обсуждение: По петрохимическим особенностям дуниты отличаются от аналогичных пород из расслоенных интрузивов и являются мантийными. Для них характерны два типа деформационных структур - протогранулярная и порфирокластовая. Они соответствуют мантийным и коровым условиям формирования. По низким концентрациям редкоземельных элементов и значениям кальций-алюминиевого отношения, существенным вариациям составов и высокой хромистости первично мантийных хромшпинелидов ультрамафиты представляют собой, скорее всего, апогарцбургитовые породы, не характерные для мантийных рифтогенных гипербазитов под континентами. Эти особенности сближают их с ультрамафитами океанических и надсубдукционных обстановок и дунитами из крупных офиолитовых комплексов Южного и Полярного Урала, в том числе и сыумкеуского. Метаморфические преобразования, проявленные в зональности хромшпинелидов и структурах оливина, происходили при температурах $520-640^{\circ} \mathrm{C}$.

Заключение: Полученные результаты дают основание предположить клиповую природу дунитгарцбургитовых тел зоны ГУР Полярного Урала.
\end{abstract}

Ключевые слова: дунит-гарцбургитовый массив, офиолиты, хромшпинелиды, метаморфизм, Полярный Урал.

Источник финансирования: Работа выполнена при поддержке программ НИР ГР № АААА-А17$117121270035-0$.

Для циитирования: Уляшева Н. С. Дуниты из гипербазитового массива зоны Главного Уральского разлома (Полярный Урал): минералогия, геохимия и условия образования // Вестник Воронежского государственного университета. Серия: Геология. 2021. № 4. С. $24-34$. DOI: https://doi.org/10.17308/geology.2021.4/3788

Контент доступен под лицензией Creative Commons Attribution 4.0 License.

\footnotetext{
๑ Уляшева Наталия Сергеевна, e-mail: nataliaulyashewa@yandex.ru
} 


\section{Введение}

На Полярном Урале в зоне Главного Уральского разлома (ГУР) западнее одного из крупнейших гипербазитового массива Сыум-Кеу присутствуют дунит-гарцбургитовые тела [1], приуроченные к верхнепротерозойским отложениям няровейской серии ЦентральноУральской тектонической зоны (рис. 1). Генезис этих пород является предметом дискуссий. Согласно одним работам [2] они относятся к ультрамафитам ампельшорского комплекса нижнего-среднего ордовика, что подразумевает их рифтогенное формирование в окраинноконтинентальной обстановке. По другим предположениям массивы принадлежат сыумкеускому дунит-гарцбургитовому офиолитовому комплексу нижнего-среднего ордовика Тагило-Магнитогорской зоны [3] и являются тектонически-эрозионными клипами.

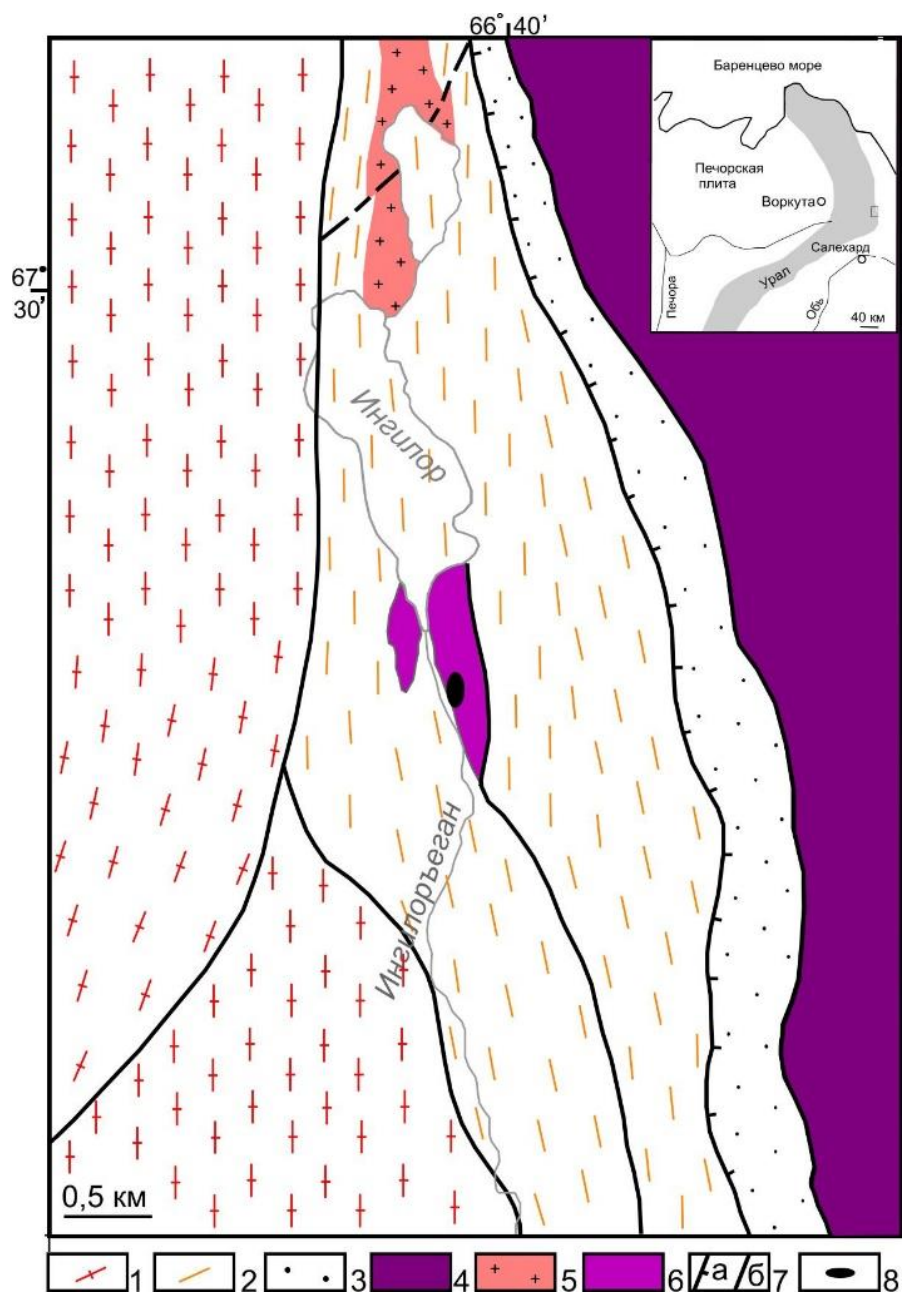

Рис. 1. Схематическая геологическая карта зоны ГУР в районе оз. Ингилор [1]. Условные обозначения по [2]: 1 - нижнепротерозойские отложения марункеуской свиты, 2 - верхнепротерозойские отложения няровейской серии; 3 - серпентинитовый меланж; 4 - сыумкеуский дунит-гарцбургитовый комплекс среднего ордовика; 5 - венд-кембрийские граниты сядатаяхинского комплекса; 6 - дунитгарцбургитовые тела ампельшорского комплекса раннего-среднего ордовика; 7 - тектонические нарушения: $a-$ Главный Уральский разлом, $\sigma$ - надвиги; 8 место отбора образцов.

[Fig. 1. Schematic geological map of the MUF zone in the Lake Ingilor area [1]. Legend according to [2]: (1) Lower Proterozoic deposits of the Marun-Keu formation, (2) - Upper Proterozoic deposits of the Nyarovey series; (3) - serpentinite melange; (4) - Syum-Keu dunite harzburgite complex of the Middle Ordovician; (5) - VendianCambrian granites of the Syadatayakhinsky complex; (6) dunite harzburgite bodes of the Ampelshor complex of the Early Middle Ordovician; (7) - tectonic faults: (a) - Main Ural Fault, (b) - thrust faults; (8) - sampling site. Translation symbols from the тар:Ингилоръеган Ingiloryegan, Печорская плита-Pechora plate, Воркута - Vorkuta, Салехард - Salekhard, Урал - Urals, Баренцево море - Barents Sea, Обь - Ob, Печора Pechora.]

Дунит-гарцбургитовые ассоциации пород, встречающиеся в складчатых областях, могут являться составной частью расслоенных интрузивов или мантийных ультрамафитовых комплексов. Среди последних выделяют подконтинентальный и офиолитовый типы $[4,5]$. Подконтинентальные ультрамафиты имеют преимущественно лерцолитовый тип разреза и характерны для корневых зон континентов и окраинно-континентальных рифтовых зон. Офиолитовые гипербазиты подразделяются на лерцолитовый и гарцбургитовый типы и образуются в срединноокеанических хребтах (COX), глубоководных желобах и окраинных морях.

Для установления генезиса формирования дунитгарцбургитовых тел зоны ГУР Полярного Урала исследованы дуниты безымянного массива шириной 350 м и длиной 1200 м, расположенного к югу от озера
Ингилор (рис. 1). Целью настоящей статьи является определение геодинамической обстановки формирования ультрамафитов и последующих метаморфических процессов на основании распределения петрогенных оксидов и редкоземельных элементов, анализа составов хромшпинелидов.

\section{Методы исследования}

Bce аналитические исследования выполнены в ЦКП «Геонаука» ИГ ФИЦ Коми НЦ УрО РАН (г. Сыктывкар). Петрографические особенности дунитов изучались под поляризационным микроскопом. Химический состав пород получен с помощью метода мокрой химии. Определение концентраций редких и рассеянных элементов выполнено путем кислотного разложения исходных образцов и дальнейшего анализа с помощью секторного масс-спектрометра Agilent 
7700x с ионизацией в индуктивно связанной плазме ICP-MS методом. Химический состав минералов исследован на сканирующем электронном микроскопе Tescan Vega 3 LMH с энергодисперсионной приставкой Instruments X-Max.

\section{Петрография и минералогия}

Петрографические исследования дунитов позволили выделить среди них два типа. Дуниты первого типа имеют пегматоидную протогранулярную петельчатую структуру и массивную текстуру (рис. 2a). Порода состоит из (об. \%) оливина (80-85), серпентина (10-
15), клинопироксена (1-2), хромшпинелида (2-3) и других рудных минералов (1-2). Субизометричные удлиненные зерна оливина размером до 6-7 мм имеют плавные грани и нередко пересекаются под углом $120^{\circ}$. Оливин по составу отвечает форстериту (Fa $-6.5-$ $7.1 \%$ ), имеет однородное погасание и замещается переплетающимися полосками серпентина. В нем наблюдаются примеси марганца $(\mathrm{MnO}-0.15-0.17 \%)$ и никеля ( $\mathrm{NiO}-0.33-0.42 \%)$. Между зернами оливина наблюдаются бесцветные идиоморфные кристаллы диопсида размером до 0.3 мм, образующие скопления в виде прожилок.
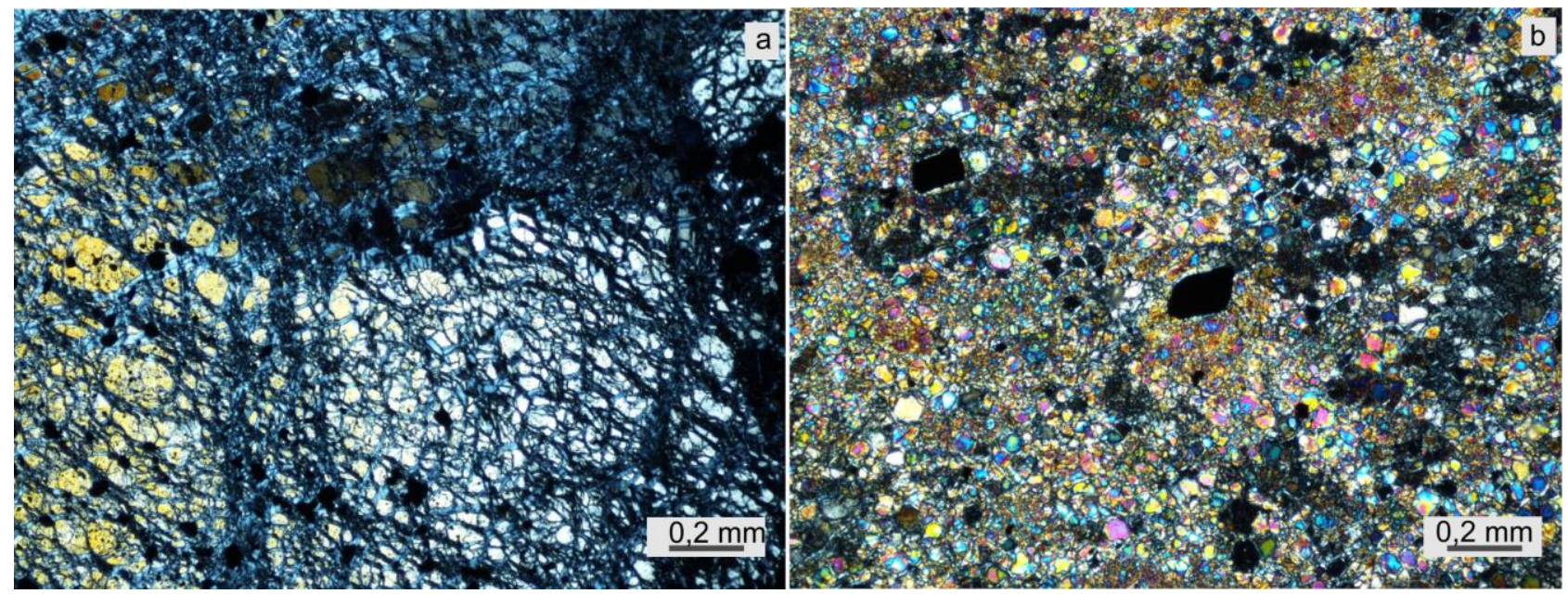

Рис. 2. Микроструктуры дунитов: $a$ - пегматоидная (протогранулярная), $b$ - порфирокластовая. Фото с анализатором.

[Fig. 2. Dunite microstructures: $(a)$ - pegmatoid (protogranular), $(b)$ - porphyroclastic. Photo with the analyser.]

Хромшпинелид представлен изометричными, призматическими удлиненными и неправильными зернами размером до 1 мм, как в виде включений в оливине, так и в интерстициях (рис. 3а). Центральные части некоторых зерен просвечивают бурым цветом. По составу хромшпинелиды имеют зональное строение - центральные части зерен соответствуют алюмохромиту, средние зоны - ферриалюмохромиту и феррихромиту по классификации [6], внешние зоны - магнетиту (рис. 4а). В центральных частях зерен хромшпинелиды имеют следующий состав (в мас.\%): $\mathrm{Cr}_{2} \mathrm{O}_{3}-45.7-50, \mathrm{Al}_{2} \mathrm{O}_{3}-21.6$ 23.8, $\mathrm{MgO}-12.1-13.3, \mathrm{FeO}-15.9-18.2, \mathrm{~V}_{2} \mathrm{O}_{5}-0-0.41$. B средних зонах появляется $\mathrm{ZnO}-0.41-0.77 \%$ и $\mathrm{MnO}-0$ $1.02 \%$, а в краевых частях $\mathrm{NiO}-0.58-0.72 \%$ (табл. 1 ).

Акцессорные рудные минералы представлены пентландитом, аваруитом $\left(\mathrm{Ni}_{3} \mathrm{Fe}\right)$ и неназванными минералами $\left(\mathrm{Ni}_{3} \mathrm{Sb},(\mathrm{FeNi})_{3}(\mathrm{AsS})_{2},(\mathrm{FeNi})_{5}(\mathrm{AsSb})_{2}\right)$ и имеют размеры не более 0.1 мм. Аваруит образует кристаллы кубической формы и присутствует в средних и краевых зонах хромшпинелидов. Удлиненные, неправильной формы зерна пентландита образуют срастания с аваруитом и с неназванными минералами (рис. 3c).

Дуниты второго типа характеризуются мелкосреднезернистой, мозаичной порфирокластовой структурой и полосчатой, линейной текстурой (рис. 2b). Они состоят из (об.\%) оливина (90-93), серпентина (3-4), хромшпинелида (1-3) и рудных минералов (1-2). Удлиненные линзовидные зерна оливина размером до 1.5 мм с зазубренными неровными ограничениями ориентированы в одном направлении и представлены форстеритом (Fa - 6.5-7.1\%). Они расположены среди мелких зерен «мозаичного» оливина, размеры которых 0.1 мм. Оливин содержит примеси марганца ( $\mathrm{MnO}-$ $0.17 \%)$ и никеля ( $\mathrm{NiO}-0.35-0.42 \%)$. Серпентин образует отдельные полосы шириной до 1-2 мм.

Хромшпинелиды не просвечивают, образуют идиоморфные, удлиненные, ромбовидные и призматические зерна размером до 1 мм (рис. 3b). Центральные зоны кристаллов представлены хромитом, средние хромитом и субферрихромитом, крайние - хроммагнетитом и магнетитом (рис. 4а). Центральные части зерен имеют следующий состав в мас.\%: $\mathrm{Cr}_{2} \mathrm{O}_{3}-62.9-67$, $\mathrm{Al}_{2} \mathrm{O}_{3}-4-7.5, \mathrm{MgO}-8.6-10.6, \mathrm{FeO}-18.9-22.2, \mathrm{~V}_{2} \mathrm{O}_{5}-$ $0-0.36$. В средних и краевых зонах наблюдаются $\mathrm{ZnO}$ $-0.36-0.61 \%$ и $\mathrm{NiO}-0-0.72 \%$.

Рудные минералы представлены шандитом $\left(\mathrm{Ni}_{3} \mathrm{~Pb}_{2} \mathrm{~S}_{2}\right)$, аваруитом $\left(\mathrm{Ni}_{3} \mathrm{Fe}\right)$, хизлевудитом $\left(\mathrm{Ni}_{3} \mathrm{~S}_{2}\right)$, неназванными минералами (( $\mathrm{Ni}_{2}(\mathrm{AsSb}), \quad \mathrm{Ni}_{3} \mathrm{Sb}$, $\left.(\mathrm{FeNi})_{5}(\mathrm{AsSb})_{2}\right)$ и серебросодержащим аурикупридом $\left(\mathrm{Au}_{2} \mathrm{Cu}_{3}\right)$. Аваруит образует срастания с неназванными минералами, шандитом и хизлевудитом (рис. $3 \mathrm{~d}, \mathrm{e})$. 


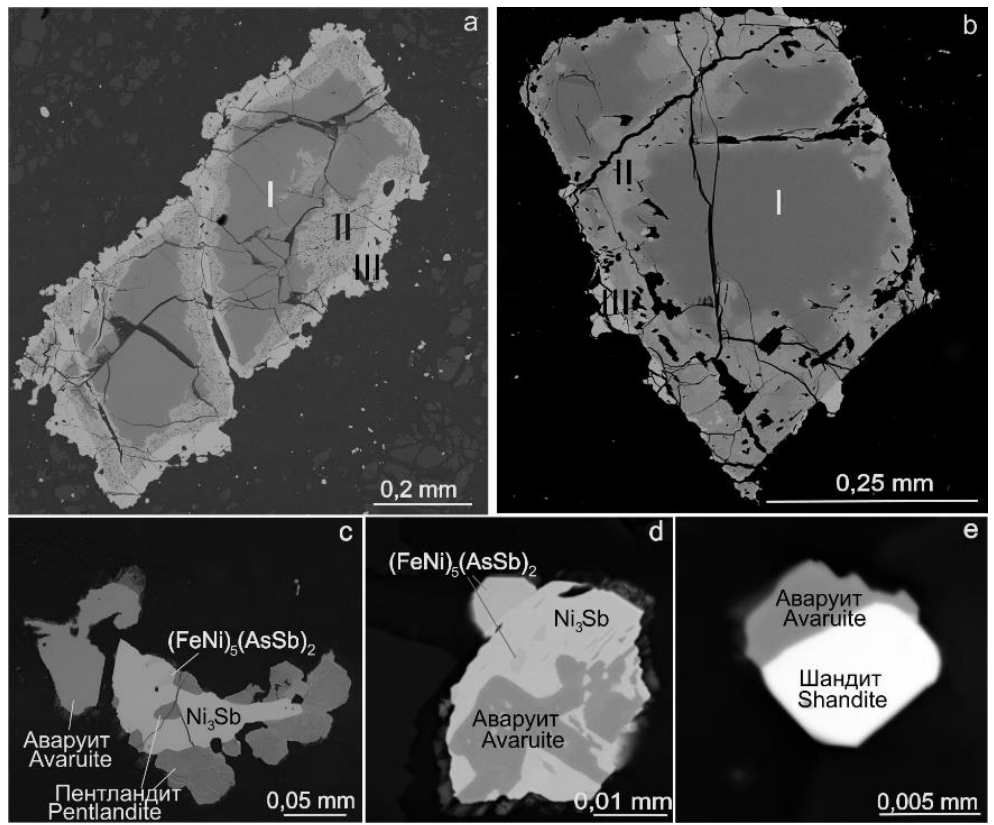

Рис. 3. BSE изображения зональных хромшпинелидов ( $a-$ протогранулярного, $b-$ порфирокластового) и других рудных минералов (c, d, e). Зоны хромшпинелидов: $I$ - центральная, $I I$ - средняя, III - краевая.

[Fig. 3. BSE images of the zoned chromespinelides $((a)$ - protogranular, $(b)$ - porphyroclastic) and other ore minerals $(c, d$, and e). Chromespinelide zoning: $I-$ core, $I I-$ middle, $I I I-$ rim.]
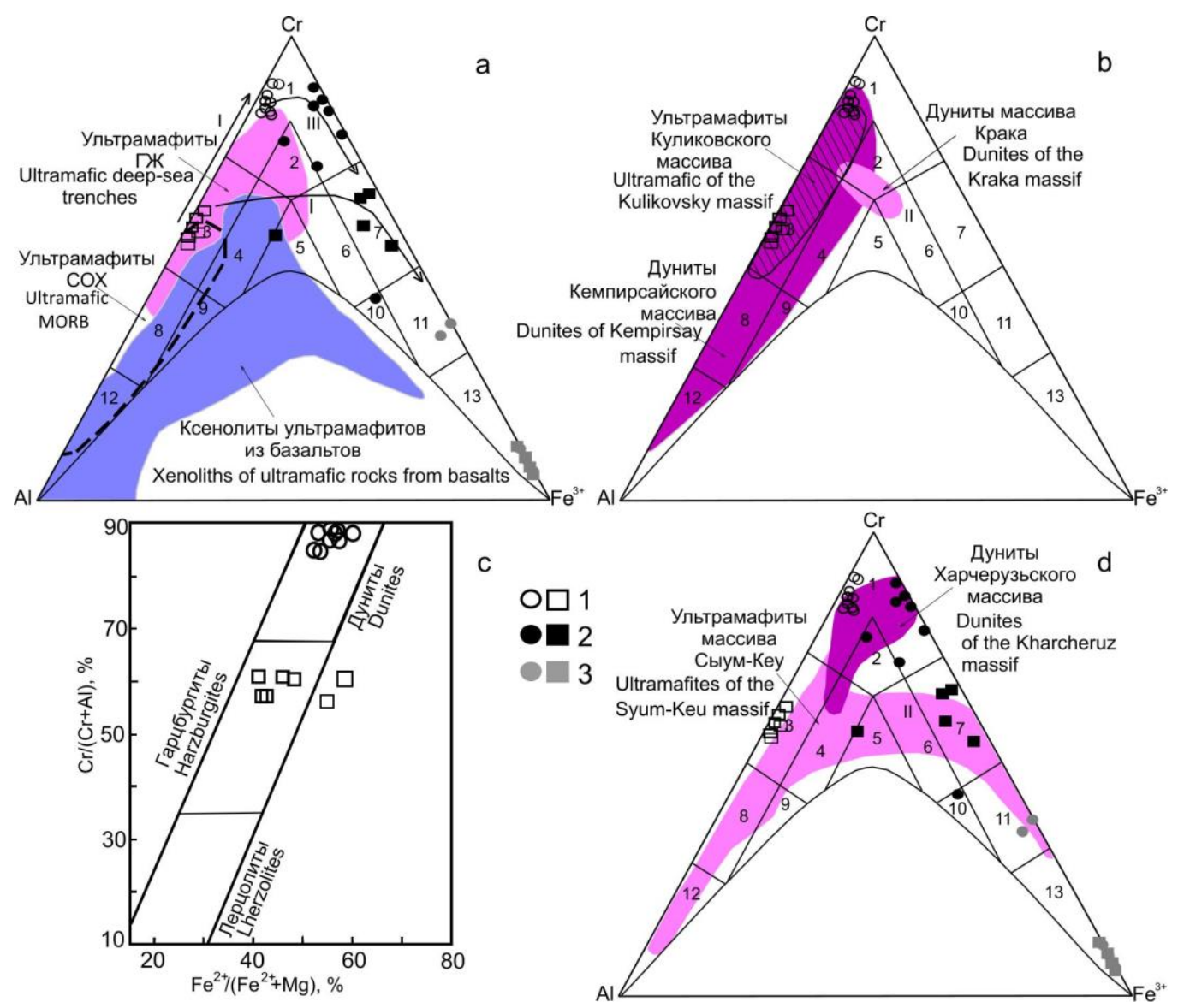

Рис. 4. Диаграммы $\mathrm{Al}-\mathrm{Cr}-\mathrm{Fe}^{3+}([6] \mathrm{a}, \mathrm{b}, \mathrm{d})$ и $\mathrm{Cr} /(\mathrm{Cr}+\mathrm{Al})-\mathrm{Fe}^{2+} /\left(\mathrm{Fe}^{2+}+\mathrm{Mg}\right)([5] \mathrm{c})$ для хромшпинелидов из дунитов. Условные обозначения. На диаграмме Н. В. Павлова: 1 - хромиты; 2 - субферрихромиты; 3 - алюмохромиты; 4 - субферриалюмохромиты; 5 - ферриалюмохромиты; 6 - субалюмоферрихромиты; 7 - феррихромиты; 8 - хромпикотиты; 9 - субферрихромпикотиты; 10 - субалюмохроммагнетиты; 11 - хроммагнетиты; 12 - пикотиты; 13 - магнетиты. Точки составов хромшпинелидов из дунитов (круги - порфирокластовых, квадраты - протогранулярных): 1 - центральных зон, 2 - средних зон, 3 - краевых зон. Поля по: a [7], b [8], с [5], d [9, 10].

[Fig. 4. $\mathrm{Al}-\mathrm{Cr}-\mathrm{Fe}^{3+}([6] \mathrm{a}, \mathrm{b}$, and $\mathrm{d})$ and $\mathrm{Cr} /(\mathrm{Cr}+\mathrm{Al})-\mathrm{Fe}^{2+} /\left(\mathrm{Fe}^{2+}+\mathrm{Mg}\right)([5] \mathrm{c})$ diagrams for chromespinelides from dunites. Legend: In the diagram by N. V. Pavlov: (1) - chromites; (2) - subferrichromites; (3) - alumochromites; (4)-subferrialumochromites; (5) - ferrialumochromites; (6) - subalumoferrichromites; (7) - ferrichromites; (8) - chromepicotites; (9) - subferrichrompicotites; (10) - subalumochromemagnetites; (11) chromemagnetites; (12) - picotites; and (13) - magnetites. Composition points for chromespinelides from dunites (circles - porphyroclastic, squares - protogranular): (I) - core zones, (II) - middle zones, and (III) - rim zones. Fields according to: a [7], b [8], c [5], and d [9, 10].] 


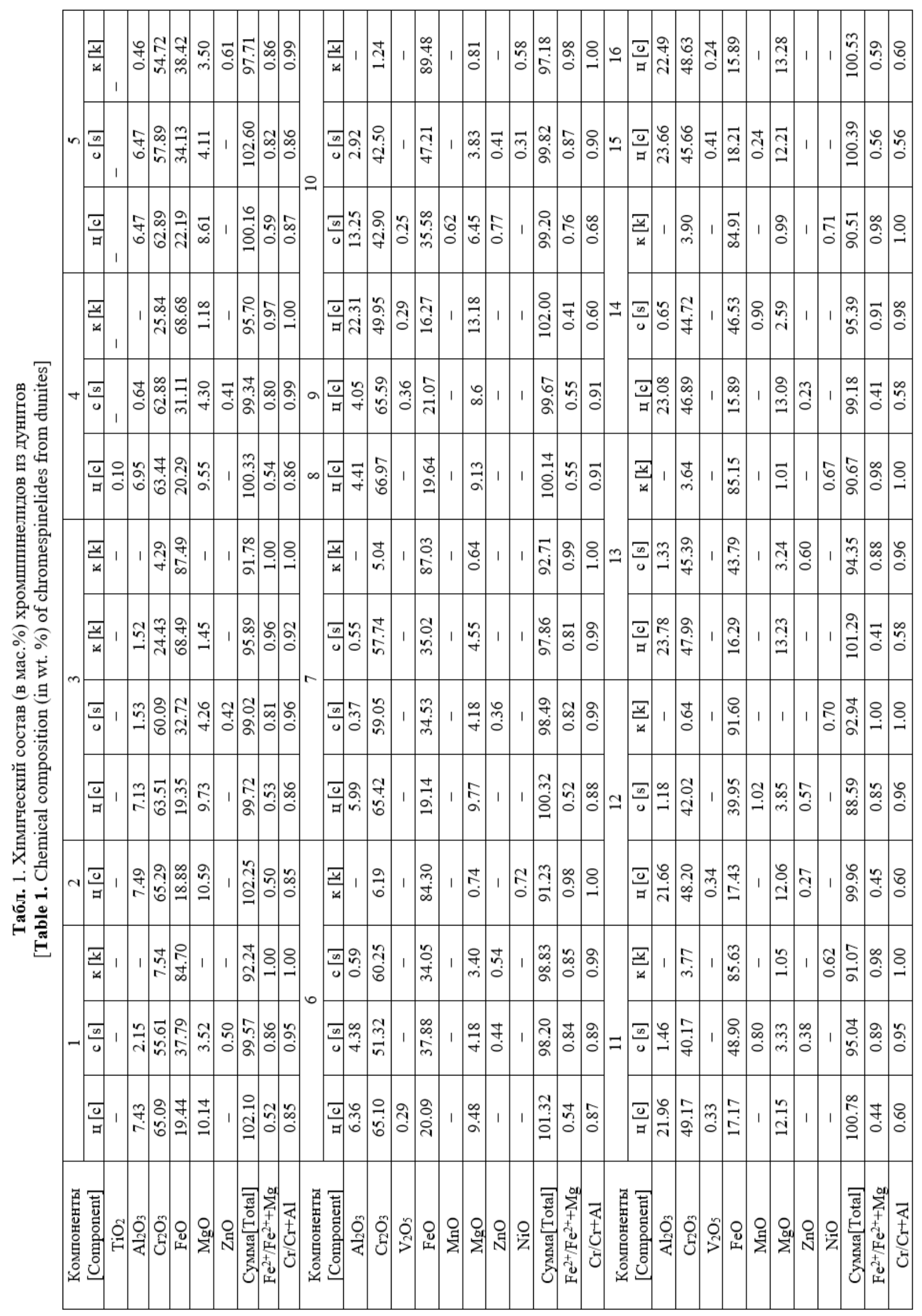


Примечания к Табл. 1: хромшпинелиды: 1-9-из дунитов с порфирокластовой структурой, 10-16 - из дунитов с протогранулярной структурой. $Ц$ - центр зерна, $c$ - средняя зона зерна, $\kappa$ - краевая зона зерна. Пробел - концентрация определяемого компонента отсутствует или ниже предела обнаружения метода.

Note to Table 1: Chromespinelides: 1-9 from dunites with a porphyroclastic structure, $10-16$ from dunites with a protogranular structure. $C$-is the center of the grain, $s-$ is the middle zone of the grain, $k$ - is the edge zone of the grain. Blank - the concentration is absent or below the detection limit of the method.

\section{Геохимия}

Дуниты отвечают натриевым магматическим обра- зованиям нормального ряда. Породы имеют низкие содержания (в мас. \%) $\mathrm{TiO}_{2}-0.01, \mathrm{SiO}_{2}-36-37$ и высокое количество $\mathrm{MgO}$ - 42-46 (табл. 2). Суммарное содержание редкоземельных элементов (Р3Э) для дунитов крайне низкое ( 2 Р3Э - 0.06-0.14 г/т). На диаграмме, где составы пород нормированы относительно состава хондрита [11], наблюдается пологий тренд распределения редкоземельных элементов с четкими минимумами иттербия (рис. 5). Дунит с порфирокластовой структурой характеризуется меньшим содержанием Р3Э, Cr (670 г/т), но повышенным $\mathrm{Ni}(2500$ г/т) по сравнению с пегматоидным дунитом $(\mathrm{Cr}-1400$ г/т, $\mathrm{Ni}-2100$ г/т).

Табл. 2. Химический состав (в мас.\%) порфирокластового (1) и протогранулярного (2) дунитов и содержания в них редких и редкоземельных элементов (в г/т)

[Table 2. Chemical composition (in wt. \%) of porphyroclastic (1) and protogranular (2) dunites and the content of rare and rare earth elements in them (in ppm)]

\begin{tabular}{|c|c|c|c|c|c|}
\hline $\begin{array}{c}\text { Компонент } \\
\text { [Component] }\end{array}$ & 1 & 2 & $\begin{array}{c}\text { Компонент } \\
\text { [Component] }\end{array}$ & 1 & 2 \\
\hline $\mathrm{SiO}_{2}$ & 36.34 & 37.34 & $\mathrm{Nd}$ & 0.025 & 0.048 \\
\hline $\mathrm{TiO}_{2}$ & 0.01 & 0.01 & $\mathrm{Sm}$ & 0.0053 & 0.0089 \\
\hline $\mathrm{Al}_{2} \mathrm{O}_{3}$ & 0.76 & 0.99 & $\mathrm{Eu}$ & 0.0033 & 0.0030 \\
\hline $\mathrm{FeO}$ & 4.08 & 3.72 & $\mathrm{Gd}$ & 0.0061 & 0.014 \\
\hline $\mathrm{Fe}_{2} \mathrm{O}_{3}$ & 2.7 & 3.02 & $\mathrm{~Tb}$ & 0.0013 & 0.0028 \\
\hline $\mathrm{MnO}$ & 0.11 & 0.099 & $\mathrm{Dy}$ & 0.0069 & 0.016 \\
\hline $\mathrm{CaO}$ & 0.1 & 0.2 & $\mathrm{Ho}$ & 0.0022 & 0.0037 \\
\hline $\mathrm{MgO}$ & 45.73 & 41.83 & $\mathrm{Er}$ & 0.0023 & 0.013 \\
\hline $\mathrm{K}_{2} \mathrm{O}$ & 0.01 & 0.01 & $\mathrm{Tm}$ & 0.0008 & 0.002 \\
\hline $\mathrm{Na}_{2} \mathrm{O}$ & 0.07 & 0.07 & $\mathrm{Yb}$ & 0.0014 & 0.0035 \\
\hline $\mathrm{P}_{2} \mathrm{O}_{5}$ & 0.0062 & 0.0039 & $\mathrm{Lu}$ & 0.0016 & 0.031 \\
\hline $\mathrm{La}$ & $\begin{array}{c}\mathrm{He} \text { обн. } \\
{[\text { Not found] }}\end{array}$ & $\begin{array}{c}\mathrm{He} \text { обн. } \\
{[\text { Not found] }}\end{array}$ & $\mathrm{Cr}$ & 670 & 1400 \\
\hline $\mathrm{Ce}$ & $\begin{array}{c}\text { He обн. } \\
\text { [Not found] }\end{array}$ & 0.013 & $\mathrm{Ni}$ & 2500 & 2100 \\
\hline $\mathrm{Pr}$ & 0.0049 & 0.014 & $\mathrm{Cu}$ & 5.4 & 5.4 \\
\hline
\end{tabular}

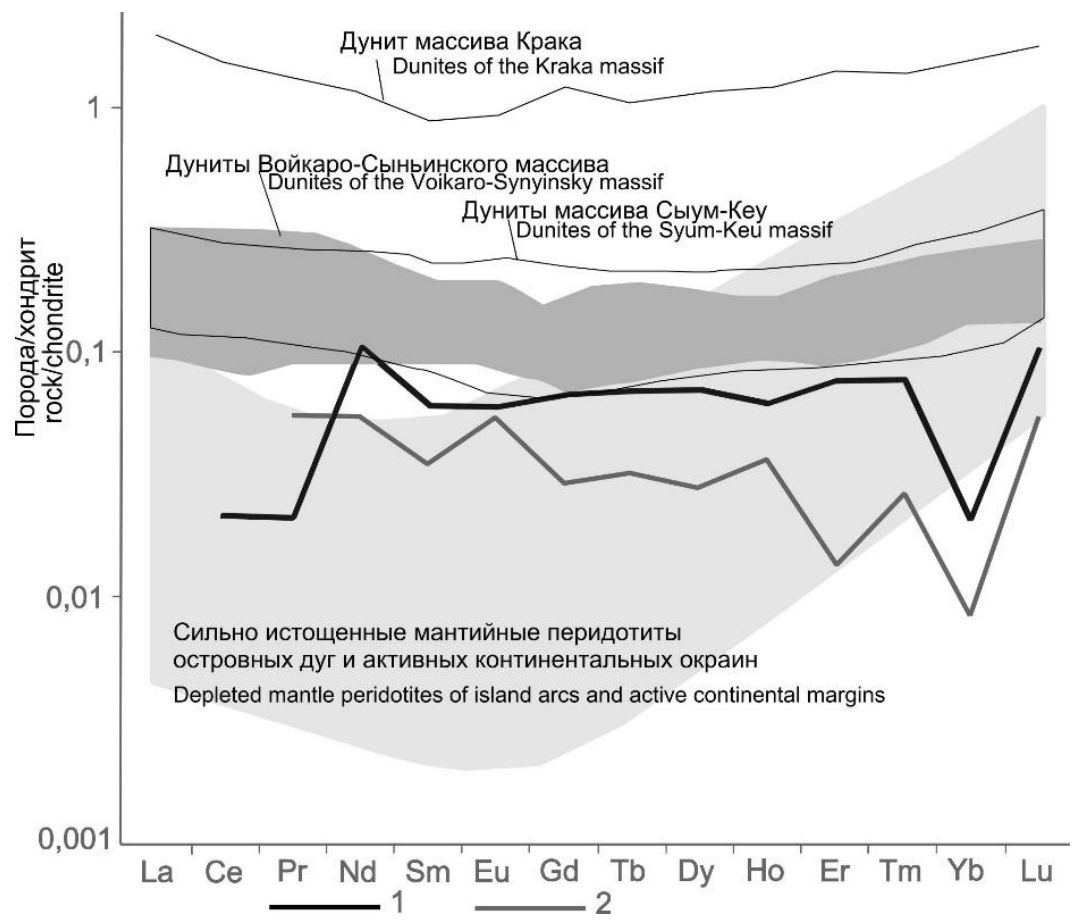

Рис. 5. Спектры содержаний редкоземельных элементов в протогранулярных (1) и порфирокластовых (2) дунитах, нормированных относительно содержаний РЗЭ в хондрите [11]. Для сравнения приведены спектры содержаний РЗЭ в ультрамафитах из массивов Крака [8], Сыум-Кеу [12], ВойкароСыньинского [13] и мантийных перидотитов островных дуг [14].

[Fig. 5. Spectra of rare earth element content in protogranular (1) and porphyroclastic (2) dunites normalised relative to REE content in chondrite [11]. For comparison, the figure shows the spectra of REE contents in ultramafic rocks from the Kraka [8], Syum-Keu [12], VoikaroSynyinsky [13] massifs, and mantle peridotites of island arcs [14].] 


\section{Обсуждение результатов}

Петрогенезис дунитов в зоне ГУР. Отсутствие кумулятивных структур в изучаемых дунитах, пониженные содержания в них глинозема (0.76-0.99\%), оксида кальция $(0.1-0.2 \%)$, оксида титана $(0.01 \%)$ и общей железистости (0.06) (табл. 1) по сравнению с дунитами расслоенных интрузивов $\left(\mathrm{Al}_{2} \mathrm{O}_{3}-1.38 \%, \mathrm{CaO}-0.43 \%\right.$, $\mathrm{TiO}_{2}-0.1 \%, \mathrm{X}_{\mathrm{Fe}}$ (железистость) - 0.13) [15], сближает эти образования с альпинотипными (мантийными) гипербазитами.

Формирование дунитов интерпретируется по-разному: они либо представляют собой рестит, образовавшийся при больших степенях плавления перидотитов [16], либо являются продуктами реакции тугоплавкого остатка с проникающими снизу расплавами или/и флюидами, сопровождающейся мантийным метасоматозом и депироксенизацией $[17,18,19]$. Дунитизация может происходить также в результате синкинематической метаморфической дифференциации гарцбургитов $[5,12]$.

Хорошо изученными являются дуниты из альпинотипных ультрамафитовых комплексов Южного Урала. В работах $[5,8]$ показано, на основании изучения геохимии пород и хромшпинелидов, что массивы западной тектонической зоны (Крака) представляют собой фрагменты верхней мантии Восточно-Европейского континента и окраинно-континентального рифта. Массивы зоны ГУР (Нурали, Кемпирсайский) и Миасс-Куликовского пояса (Калкинский, Куликовский) сформировались соответственно в океанической и островодужной обстановках. На Полярном Урале наиболее изучены крупные ультрамафитовые массивы Хадатинского (Сыум-Кеу, Харчерузь) и Войкаро-Сыньинского поясов, расположенных к востоку от ГУР. Массив Харчерузь, по-видимому, является клипом от массива Сыум-Кеу. Превалирует мнение, что это фрагменты литосферы океанического типа [20], переработанные сначала при частичном плавлении протомантийного вещества, а затем в ходе флюидно-магматической депироксенизации над зоной субдукции [12].

Пегматоидные или протогранулярные и порфирокластовые типы микроструктур, характерные для исследуемых дунитов, отражают степень пластической деформации пород соответственно в мантийных и коровых условиях. Дунит с протогранулярной структурой формируется в твердом субстрате в процессе депироксенизации мантийных ультрамафитов, сопровождающейся рекристаллизацией отжига при температурах более $1000^{\circ} \mathrm{C}$. Ультрамафиты с порфирокластовой структурой образуются в результате интенсивных деформаций, при которых происходит синтектоническая рекристаллизация зерен протогранулярного оливина [9]. Дуниты с деформационными структурами характерны для мантийного среза офиолитовых комплексов, в том числе массивов Полярного Урала: Сыум-Кеу и Харчерузь $[9,12]$.

Геохимическая типизация. Значения $\mathrm{Ca}-\mathrm{Al}$ отношения и распределение РЗЭ являются важными критериями деплетированности ультрабазитов [4] с учетом изохимического характера метаморфизма [13]. Предельно низкие значения $\mathrm{CaO} / \mathrm{Al}_{2} \mathrm{O}_{3}$ в дунитах, соответствующие 0.13-0.2, свидетельствуют о сильной истощенности пород. Подобные низкие значения имеют гипербазиты офиолитового типа зоны ГУР и Миасс-Куликовского пояса Южного Урала [4].

Низкие содержания редкоземельных элементов, в 10-50 раз ниже хондритовых, также указывает на сильную деплетированность ультрамафитов. Спектр распределения РЗЭ располагается в области сильно истощенных мантийных перидотитов островных дуг и активных континентальных окраин [14] (рис. 5). В отличие от этих перидотитов, имеющих U-образный профиль, изучаемые дуниты образуют пологий спектр распределения РЗЭ, характерный для некоторых дунитов из дунит-гарцбургитовых комплексов массивов Полярного Урала $[12,13]$ : Войкаро-Сыньинского и СыумКеуского. Изучаемые породы отличаются от дунитов массива Крака резко пониженным количеством РЗЭ.

Чтобы исключить влияние наложенных преобразований на оценку степени частичного плавления (F) породы, для расчета этого параметра использовано содержание глинозема в дуните [21]. Рассчитанные значения F соответствуют 18-21\%, которые, скорее всего, характеризуют степень плавления гарцбургита при образовании дунита.

Хромшпинелиды как индикаторы геодинамических обстановок. Акцессорные хромшпинелиды часто используются в качестве индикаторов геодинамических обстановок формирования и метаморфических изменений пород [22]. В хромшпинелидах изучаемых дунитов наблюдается увеличение хромистости, железистости и уменьшение глинозема и магнезиальности от центра к периферии зерен. Центральные зерна минералов отвечают, скорее всего, неметаморфизованным разностям - первично-мантийным хромшпинелидам. Тренд (I) Al-Cr составов центральных частей характеризует степень деплетированности мантийного источника (рис. 4a). Порфирокластовые дуниты, согласно этому тренду, наиболее деплетированы по сравнению с протогранулярными разновидностями. Если сравнивать составы центральных частей хромшпинелидов с составами этих минералов из мантийных ультрамафитов разных геодинамических обстановок [7], то они наиболее близки к хромшпинелидам пород глубоководных желобов и частично СОХ (рис. 4a).

На тройной диаграмме (рис. 4b) точки составов хромшпинелидов из дунитов Кемпирсайского и Куликовского массивов образуют широкий разброс, а точки составов хромшпинелидов из дунитов массива Крака компактное поле. При сравнении составов изучаемых неметаморфизованных хромшпинелидов с ними видно, что они наиболее близки к минералам из пород Кемпирсайского и Куликовского массивов.

И. С. Чащухин предполагает [5], что дуниты подконтинентального типа образуются за счет частичного плавления пиролита мантии, при этом величина хромистости хромшпинелидов постепенно увеличивается от лерцолитов (15-35\%) к гарцбургитам (35-65\%) и 
далее к дунитам (85\%). Дуниты офиолитового типа образуются за счет гарцбургитов в результате их реакции с проникающими снизу расплавами. В этом случае дуниты наследуют признаки гарцбургитов. На рис. 4c приведены поля составов хромшпинелидов из дунитгарцбургит-лерцолитовой серии подконтитнетальных массивов Южного Урала, где они четко локализуются по типам пород. Точки составов изучаемых хромшпинелидов попадают в поля гарцбургитов и дунитов, из чего, скорее всего, следует, что изучаемые дуниты сформировались по гарцбургитам.

Сравнивая составы изучаемых хромшпинелидов с составами этого минерала из расположенных восточнее ультрамафитов массивов Сыум-Кеу и Харчерузь видно (рис. 4d), что наблюдается схожесть, как первичных составов, так и вторичных - метаморфизованных разностей.

Оливины из порфирокластовых дунитов имеют повышенную железистость по сравнению с оливинами из протогранулярных ультрамафитов. По содержаниям фаялитового компонента и никеля $(\mathrm{Fa}-6.5-9 \%$ и $\mathrm{NiO}$ $-0.3-0.4 \%$ ) они близки к оливинам из дунитов дунитграцбургитового комплекса Сыум-Кеу (Fa - 6-8.5\% и $\mathrm{NiO}-0.3-0.6 \%)[23]$.

Метаморфизм дунитов. Составы средних и краевых зон хромшпинелидов отвечают вторичным преобразованиям и изменяются в направлении увеличения хромистости и железистости (тренды II и III), что связано с процессами корового метаморфизма (рис. 4а). В средних зонах наблюдается снижение содержаний $\mathrm{Al}$ и $\mathrm{Mg}$. Вынос этих элементов в силикатные минералы происходит при средне- и высокотемпературном метаморфизме [10]. Признаками эпигенетических процессов являются также обогащение хромшпинелидов в средних зонах цинком, а в краевых частях - никелем [24]. Полагая, что перекристаллизация оливина и образование средних зон хромшпинелидов в порфирокластовых дунитах происходили одновременно в коре, то можно использовать оливин-хромшпинелевый геотермометр Фабри [25], как самый надежный и универсальный [26] для расчета Р-Т условий метаморфизма. Расчетная температура перекристаллизации дунитов составила $530-560^{\circ} \mathrm{C}$. С этими результатами хорошо коррелируются значения температур $-520-640^{\circ} \mathrm{C}$, рассчитанные по шпинелевому геотермометру, основанному на содержании цинка в хромшпинелидах [27]. Увеличение степени метаморфизма приводит к выносу хрома и накоплению железа. В результате вторичных процессов в дунитах формируются рудные минералы шандит, аваруит, хизлевудит, аурикуприд и др.

\section{Заключение}

Петрографические, геохимические и минералогические исследования дунитов из дунит-гарцбургитового массива зоны ГУР Полярного Урала показали, что они представляют собой мантийные породы с признаками деформационных структур: протогранулярной и порфирокластовой. По распределению РЗЭ и Са-Al отношению в породах, составам хромшпинелидов и оливинов, они отличаются от подконтинентальных рифтогенных гипербазитов и отождествляются с дунитами из крупных мантийных комплексов офиолитового типа Южного и Полярного Урала. Существенные вариации составов первично-мантийных хромшпинелидов, скорее всего, указывает на то, что дуниты сформировались по гарцбургитам и унаследовали их признаки. Сильная истощенность дунитов РЗЭ и высокая хромистость хромшпинелидов могут свидетельствовать о надсубдукционной природе пород. Метаморфические преобразования, выявленные по зональности хромшпинелидов и структуре оливина, происходили при температурах 520-640 ${ }^{\circ} \mathrm{C}$.

Полученные результаты дают возможность предположить клиповую природу мелких дунит-гарцбургитовых тел зоны ГУР Полярного Урала.

Конфликт интересов: Авторы декларируют отсутствие явных и потенциальных конфликтов интересов, связанных с публикацией настоящей статьи.

\section{ЛИТЕРАТУРА}

1. Добрецов Н. Л., Молдаванцев Ю. Е., Казак А. П., Пономарева Л. Г., Савельева Г. Н., Савельев А. А. Петрология и метаморфизм древних офиолитов (на примере Полярного Урала и Западного Саяна). Новосибирск: Наука, 1977. Вып. $368.221 \mathrm{c}$

2. Государственная геологическая карта Российской Федерации. Масштаб 1:1000000 (третье поколение). Серия Западно-Сибирская. Лист Q-42 -Салехард. Объяснительная записка. СПб.: Картографическая фабрика ВСЕГЕИ, 2014. $396 \mathrm{c}$.

3. Государственная геологическая карта Российской Федерации масштаба 1:200 000. Издание второе. Серия Полярно-Уральская. Лист R Q-42-I, II (Лаборовая). Объяснительная записка. СПб.: ВСЕГЕИ, 2009. 372 с.

4. Савельев Д. Е., Сначёв В. И., Сначёв А. В., Романовская М. А. Геолого-геохимическая зональность базит-гипербазитового магматизма Южного Урала // Вестник Московского университета. 2006. №1. С. 27-33.

5. Чащухин И. С. О генетических типах дунитов в ультрамафитах складчатых областей (на примере Урала) // Известия Уральского государственного горного универсиmema. 2019. № 2. C. 42-48. https://doi.org/10.21440/23072091-2019-2-42-48

6. Павлов Н. В. Химический состав хромшпинелидов в связи с петрографическим составом пород ультраосновных интрузивов. Труды Геол. ин-та АН СССР. 1949. 87 с.

7. Barnes S.J., Roeder P.L. The range of spinel compositions in terrestrial mafic and ultramafic rocks // Journal of Petrology. 2001. Vol. 42. № 12. P. 2279-2302.

8. Савельев Д. Е. Хромитоносность гипербазитовых массивов Южного Урала: автореф. дис. ... д-ра геол.-минерал. наук. Пермь, 2012. 42 с.

9. Чернышов А. И., Юричев А. Н. Структурная эволюция дунитов и хромитов харчерузского массива (Полярный Урал) // Геотектоника. 2016. № 2. C. 62-77. DOI: $10.7868 / \mathrm{S} 0016853 \mathrm{X} 1602003 \mathrm{X}$

10. Перевозчиков Б. В., Плотников А. В., Макиев Т. Т. Природа вариаций состава рудной и акцессорной хромшпинели ультрабазитового массива Сыум-Кеу (Полярный Урал) // Известия ВУЗов. Геология и разведка. 2007. № 4. С. 32-39. 
11. Sun S. S., McDonough W. F. Chemical and isotopic systematics of oceanic basalts: implications for mantle composition and processes. Magmatism in the oceanic basins. Geol. Soc. Spec. $\begin{array}{lllll}\text { Publ. } & 1989 . & \text { № } & 42 . & \text { P. }\end{array}$ DOI:10.1144/GSL.SP.1989.042.01.19

12. Шмелев В. Р. Мантийные ультрабазиты офиолитовых комплексов Полярного Урала: петрогенезис и обстановка формирования // Петрология. 2011. Т. 19. № 6. С. 649-672.

13. Прудников И. А. Генетическая типизация дунитов альпинотипных массивов Урала на основе характера распределения редкоземельных элементов // Разведка $u$ охрана недр. 2021. № 3. С. 11-25.

14. Лазько Е. Е., Шарков Е. В., Богатиков О. А. Мантийные субстраты, их геохимическая типизация и роль в образовании подкоровых магм // Геохимия. 1993. № 2. С. $165-189$.

15. Алексеев А. А., Алексеева Г. В., Ковалев С. Г. Расслоенные интрузии западного склона Урала. Уфа, "Гилем", 2000. $188 \mathrm{c}$.

16. Рингвуд А. Е. Состав и петрология мантии Земли. М.: Недра, 1981.585 с.

17. Батанова В. Г., Савельева Г. Н. Миграция расплавов в мантии под зонами спрединга и образование дунитов замещения: обзор проблемы // Геология и геофизика. 2009. Т. 50. № 9. С. 992-1012.

18. Kelemen P., Dick H. J. B., Quick J. Formation of harzburgite by pervasive melt/rock reaction on the upper mantle // Nature. 1992. Vol. 358. P. 635-641. https://doi.org/10.1038/358635a0
19. Takahashi N. Evidence for melt segregation towards fractures in the Horoman mantle peridotite complex // Nature. 1992. Vol. 359. P. 52-55.

20. Пучков В. Н. Геология Урала и Приуралья (актуальные вопросы стратиграфии, тектоники, геодинамики и металлогении). Уфа: ДизайнПолиграфСервис, 2010. 280 с.

21. Чащухин И. С. О количественной оценке степени частичного плавления ультрамафитов. Ежегодник (Тр. ИГГ УрО РАН). Вып. 164. 2017. С. 191-192.

22. Паланджян С. А. Типизация мантийных перидотитов по геодинамическим обстановкам формирования. Магадан: СВКНИИ ДВО РАН, 1992.104 с.

23. Макеев А. Б. Минералогия альпинотипных ультрабазитов. СПб: Наука, 1992. $197 \mathrm{c.}$

24. Силаев В. И., Шабалин В. Н., Голубева И. И., Хазов А. Ф., Белоусова Е. А. О цинксодержащих и цинкистых хромшпинелидах Тимано-Уральского региона // Вестник Института геологии Коми НЦ УрО РАН. 2008. № 8 (199). С. 6-16. 25. Fabries J. Spinel-olivine geotermometry in peridotites from ultramafic complexes // Contributions to Mineralogy and Petrology. 1979. Vol. 69. № 4. P. 329-336.

26. Юричев А. Н. Оливин-хромшпинелевые геотермометры - отражение термических параметров кристаллизации // Металлогения древних и современных океанов. 2015. № 1. C.59-63.

27. Griffin W. L., Sobolev, N. V., Ryan C. G., Pokhilenko, N. P, Win T. T., Yefimova Y. Trace elements in garnets and chromites: diamond formation in the Siberian lithosphere// Lithos. 1993. Vol. 29. P. 235-256.
Улямева Наталия Сергеевна - к.г.-м.н, н. с., Институт геологии им. академика Н. П. Юшкина ФИЦ Коми научного центра Уральского отделения Российской академии наук, Сыктывкар; e-mail: nataliaulyashewa@yandex.ru; ORCID https://orcid.org/0000-0001-5744-0478

Автор прочитал и одобрил окончательный вариант рукописи.
Natalia S. Ulyasheva - PhD in Geol-Min., research fellow, Institute of Geology of Komi Science Center of the Ural Branch of the Russian Academy of Sciences, Syktyvkar, e-mail: nataliaulyashewa@yandex.ru; ORCID https://orcid.org/0000-0001-5744-0478

Author have read and approved the final manuscript. 
UDC 552.321.6 (234.851)

DOI: https://doi.org/10.17308/geology.2021.4/3788

ISSN 1609-0691

Received: 19.10 .2021

Accepted: 01.12.2021

Published online: 17.12 .2021

\title{
Dunites from the hyperbasite massif of the Main Ural Fault zone (Polar Urals): mineralogy, geochemistry and formation conditions
}

\author{
C2021 N. S. Ulyasheva ${ }^{\circledR}$ \\ Institute of Geology named after Academician N. P. Yushkin of Komi \\ Science centre of the Ural Branch of the Russian Academy of Sciences, \\ 54 Pervomayskaya ul., Syktyvkar 167982, Russian Federation
}

\begin{abstract}
Introduction: In the Main Ural Fault (MUF) area of the Polar Urals, dunite harzburgite bodies of uncertain genesis are localised in the Upper Proterozoic sediments of the Nyarovey series of the western tectonic zone. They are either marginal continental riftogenic formations of the Lower Middle Ordovician or tectonic erosion klippes of the dunite-harzburgite complex of the ophiolite Syum-Keu massif located to the east. The aim of the study was to determine the conditions for the formation of hyperbasite bodies based on mineralogical and geochemical studies of dunites from the massif near Ingilor Lake.

Methodology: We carried out petrographic, petrogeochemical, and mineralogical studies of dunites using precision methods. We studied the structural features and compositions of ultramafic rocks and minerals (chromespinelides and olivines) which clearly indicate mantle and crustal processes.

Results and discussion: By their petrochemical features, dunites differ from similar rocks from stratified intrusive bodies, as they are mantle rocks. Typically, they have two types of deformational structures: protogranular and porphyroclastic, which correspond to the conditions of mantle and crustal formation. Due to the low concentration of rare earth elements, values of calcium-aluminium ratio, significant variations in compositions, and high chromium content of primary mantle chromespinelides, ultramafic rocks are most likely apoharzburgite rocks, which are not typical for mantle riftogenic continental hyperbasites. These features make them similar to ultramafic rocks of oceanic and supra-subduction zones and dunites from large ophiolite complexes of the Southern and Polar Urals, including the SyumKeu complex. Metamorphic transformations shown in chromespinelide zoning and olivine structures occurred at temperatures of $520-640^{\circ} \mathrm{C}$.

Conclusions: The results suggest that the dunite harzburgite bodies in the MUF zone of the Polar Urals are of a klippe nature.
\end{abstract}

Keywords: dunite harzburgite massif, ophiolite, chromespinelide, metamorphism, Polar Urals.

Funding: The study was supported by R\&D programs, state registration No. AAAA-A17-117121270035-0.

For citation: Ulyasheva N. S. Dunites from the hyperbasite massif of the Main Ural Fault zone (Polar Urals): mineralogy, geochemistry and formation conditions. Vestnik Voronezhskogo gosudarstvennogo universiteta. Seriya: Geologiya - Proceedings of Voronezh State University. Series: Geology, 2021, no. 4, pp. 24-34. DOI: https://doi.org/10.17308/geology.2021.4/3788

Conflict of interests: The authors declare the absence of obvious and potential conflicts of interest related to the publication of this article.

The content is available under Creative Commons Attribution 4.0 License.

Natalia S. Ulyasheva, e-mail: nataliaulyashewa@yandex.ru 


\section{REFERENCES}

1. Dobrecov N. L., Moldavancev Ju. E., Kazak A. P., Ponomareva L.G., Savelyeva G. N., Savelyev A. A. Petrologija i metamorfizm drevnih ofiolitov (na primere Poljarnogo Urala i Zapadnogo Sajana) [Petrology and metamorphism of ancient ophiolites (on the example of the Polar Urals and Western Sayan)]. Novosibirsk, Nauka publ., 1977, issue. 368, 221 p. (in Russ.).

2. Gosudarstvennaya geologicheskaya karta Rossiiskoi Federatsii. Masshtab 1:1000000 (tret'e pokolenie). Seriya Zapadno-Sibirskaya. List Q-42 -Salekhard. Ob"yasnitel'naya zapiska. [State geological map of the Russian Federation. Scale 1: 1000000 (third generation). Series West Siberian. Sheet Q-42. Explanatory note]. Saint Petersburg, VSEGEI publ., 2014. Salekhard, 396 p. (in Russ.).

3. Gosudarstvennaya geologicheskaya karta Rossiiskoi Federatsii masshtaba 1:200 000. Izdanie vtoroe. Seriya Polyarno-Ural'skaya. List $R$ Q-42-I, II (Laborovaya). Ob"yasnitel'naya zapiska. [State Geological Map of the Russian Federation, scale 1: 200,000. Second edition. The Polar-Ural series. Sheet Q-42-I, II (Labor). Explanatory note]. Saint Petersburg, VSEGEI publ., 2009, 372 p. (in Russ.).

4. Savel'ev D. E., Snachev V. I., Snachev A. V., Romanovskaya M. A. Geologo-geokhimicheskaya zonal'nost' bazit-giperbazitovogo magmatizma Yuzhnogo Urala [About genetic types of dunites in ultramafic rocks of folded regions (by the example of the Urals)]. Vestnik Moskovskogo universiteta - Bulletin of the Ural State Mining University, 2006, no. 1, pp. 27-33. (in Russ.).

5. Chashchukhin I. S. O geneticheskikh tipakh dunitov v ul'tramafitakh skladchatykh oblastei (na primere Urala) [On genetic types of dunites in ultramafic folded regions (for example the Urals)] Izvestiya Ural'skogo gosudarstvennogo gornogo universiteta. - News of the Ural State Mining University, 2019, no. 2, pp. 42-48. DOI: 10.21440/2307-2091-2019-2-42-48 (in Russ.).

6. Pavlov N. V. Khimicheskii sostav khromshpinelidov v svyazi s petrograficheskim sostavom porod ul'traosnovnykh intruzivov [Chemical composition of Cr-spinels in connection with the petrographic composition of rocks of ultrabasic intrusions]. Trudy Geol. in-ta AN SSSR. [Proceedings of Geol. Institute of the USSR Academy of Sciences], 1949, 87 p. (in Russ.).

7. Barnes S. J., Roeder P. L. The range of spinel compositions in terrestrial mafic and ultramafic rocks. Journal of Petrology, 2001, vol. 42 , no. 12 , pp. 2279-2302.

8. Savel'ev D. E. Khromitonosnost' giperbazitovykh massivov Yuzhnogo Urala: avtoref. dis. ... d-ra geol.-mineral. nauk [Chromite content of hyperbasite massifs of the Southern Urals: theses author. dis. ... Dr. Geol.-Mineral. Sciences]. Perm, 2012. 42 p. (in Russ.).

9. Chernyshov A. I., Yurichev A. N. Strukturnaya evolyutsiya dunitov i khromitov kharcheruzskogo massiva (Polyarnyi Ural) [Structural evolution of dunites and chromites of the Kharcheruz massif (Polar Urals)]. Geotektonika - Geotectonics, 2016, no. 2, pp. 62-77. DOI: 10.7868/S0016853X1602003X (in Russ.).

10. Perevozchikov B. V., Plotnikov A. V., Makiev T. T. Priroda variatsii sostava rudnoi i aktsessornoi khromshpineli ul'trabazitovogo massiva Syum-Keu (Polyarnyi Ural) [The nature of variations in the composition of ore and accessory chrome spinel of the Syum-Keu ultramafic massif (Polar Urals)]. Izvestiya VUZov. Geologiya $i$ razvedka - Izvestiya VUZov. Geology and exploration, 2007, no. 4, pp. 32-39. (in Russ.).

11. Sun S. S., McDonough W. F. Chemical and isotopic systematics of oceanic basalts: implications for mantle composition and processes. Magmatism in the oceanic basins. Geol. Soc. Spec. Publ, 1989, no. 42, pp. 313-345. DOI:10.1144/GSL.SP.1989.042.01.19

12. Shmelev V. R. Mantiinye ul'trabazity ofiolitovykh kompleksov Polyarnogo Urala: petrogenezis i obstanovka formirovaniya [Mantle ultrabasic rocks of ophiolite complexes of the Polar Urals: petrogenesis and formation environment]. Petrologiya - Petrology, 2011, vol. 19, no. 6, pp. 649-672. (in Russ.).

13. Prudnikov I. A. Geneticheskaya tipizatsiya dunitov al'pinotipnykh massivov Urala na osnove kharaktera raspredeleniya redkozemel'nykh elementov [Genetic typification of dunites of alpine-type massifs of the Urals based on the nature of the distribution of rare-earth elements]. Razvedka i ohrana nedr - Exploration and conservation of mineral resources, 2021, no. 3, pp. 11-25. (in Russ.).

14. Laz'ko E. E., Sharkov E. V., Bogatikov O. A. Mantiinye substraty, ikh geokhimicheskaya tipizatsiya i rol' $\mathrm{v}$ obrazovanii podkorovykh magm [Mantle substrates, their geochemical typification and role in the formation of subcrustal magmas]. Geokhimiya-Geochemistry, 1993, no. 2, p. 165-189. (in Russ.).

15. Alekseev A. A., Alekseeva G. V., Kovalev S. G. Rassloennye intruzii zapadnogo sklona Urala [Layered intrusions of the western slope of the Urals]. Ufa, Gilem publ., 188 p. (in Russ.).

16. Ringvud A. E. Sostav i petrologiya mantii Zemli [Composition and petrology of the Earth's mantle]. Moscow, Nedra publ., 1981, 585 p. (in Russ.).

17. Batanova V. G., Savel'eva G. N. Migratsiya rasplavov v mantii pod zonami spredinga i obrazovanie dunitov zameshcheniya: obzor problemy [Migration of melts in the mantle beneath spreading zones and the formation of replacement dunites: an overview of the problem]. Geologiya i geofizika - Geology and Geophysics, 2009, vol. 50, no. 9, pp. 992-1012. (in Russ.).

18. Kelemen P., Dick H. J. B., Quick J. Formation of harzburgite by pervasive melt/rock reaction on the upper mantle. Nature, 1992, vol. 358, pp. 635-641. https://doi.org/10.1038/358635a0

19. Takahashi N. Evidence for melt segregation towards fractures in the Horoman mantle peridotite complex. Nature, 1992, vol. 359, pp. $52-55$.

20. Puchkov V. N. Geologiya Urala i Priural'ya (aktual'nye voprosy stratigrafii, tektoniki, geodinamiki $i$ metallogenii) [Geology of the Urals and the Urals (topical issues of stratigraphy, tectonics, geodynamics and metallogeny)]. Ufa, DizainPoligrafServis, publ., 2010, 280 p. (in Russ.).

21. Chashchukhin I. S. O kolichestvennoi otsenke stepeni chastichnogo plavleniya ul'tramafitov $[\mathrm{On}$ the quantitative assessment of the degree of partial melting of ultramafic rocks]. Ezhegodnik (Tr. IGG UrO RAN) [Yearbook (Proceedings of the IGG Ural Branch of the Russian Academy of Sciences)], Vol. 164, 2017. pp. 191-192. (in Russ.).

22. Palandzhyan S. A. Tipizatsiya mantiinykh peridotitov po geodinamicheskim obstanovkam formirovaniya [Typification of mantle peridotites by geodynamic setting of formation]. Magadan, SVKNII DVO RAN publ., 1992, 104 p. (in Russ.).

23. Makeev A. B. Mineralogiya al'pinotipnykh ul'trabazitov [Mineralogy of alpine-type ultramafic rocks]. SPb, Nauka publ., 1992, 197 p. (in Russ.).

24. Silaev V. I., Shabalin V. N., Golubeva I. I., Khazov A. F., Belousova E. A. O tsinksoderzhashchikh i tsinkistykh khromshpinelidakh Timano-Ural'skogo regiona [On zinc-containing and zinccontaining chrome spinels of the Timan-Ural region]. Vestnik Instituta geologii Komi NC UrO RAN - Bulletin of the Institute of Geology of the Komi Scientific Center of the Ural Branch of the Russian Academy of Sciences, 2008, no. 8, p. 6-16. (in Russ.)

25. Fabries J. Spinel-olivine geotermometry in peridotites from ultramafic complexes. Contributions to Mineralogy and Petrology, 1979, vol. 69, no. 4, pp. 329-336.

26. Yurichev A. N. Olivin-khromshpinelevye geotermometry otrazhenie termicheskikh parametrov kristallizatsii [Olivine-Crspinel geothermometers - reflection of thermal parameters of crystallization]. Metallogeniya drevnikh i sovremennykh okeanovMetallogeny of ancient and modern oceans, 2015, no. 1, p. 59-63. (in Russ.).

27. Griffin W. L., Sobolev, N. V., Ryan C. G., Pokhilenko, N. P, Win T. T. and Yefimova, Y. Trace elements in garnets and chromites: diamond formation in the Siberian lithosphere. Lithos, 1993, vol. 29, pp. 235-256. 